\title{
Kemampuan Pemecahan Masalah Matematis Siswa Melalui Model Pembelajaran learning Cycle 7E dan Problem Based Learning
}

\author{
Puji Lestari ${ }^{*}$ dan Rina Rosdiana ${ }^{2}$ \\ 1Program Studi Pendidikan Matematika, Institut Pendidikan Indonesia (IPI) Garut \\ Garut, Jawa Barat, Indonesia \\ puji.l.hendayani@gmail.com
}

\author{
${ }^{2}$ SMPN 1 Tarogong Kidul \\ Garut, Jawa Barat, Indonesia \\ rinarosdiana25@gmail.com
}

Artikel diterima: 5 Agustus 2018, direvisi: 21 September 2018, diterbitkan: 30 September 2018

\begin{abstract}
Abstrak
Kemampuan pemecahan masalah merupakan bagian dari kurikulum pendidikan matematika saat ini. Fakta di lapangan menunjukkan bahwa kemampuan pemecahan masalah matematis siswa masih belum optimal, salah satu penyebabnya adalah masih banyak siswa yang menemui kesulitan dalam hal pemahaman konsep dasar. Mengoptimalkan kemampuan pemecahan masalah diantaranya dapat ditempuh melalui pembelajaran yang berpusat pada siswa. Model pembelajaran Learning Cycle $7 E$ dan Problem Based Learning merupakan dua dari beragam model pembelajaran yang berpusat pada siswa. Adapun tujuan dari penelitian ini adalah untuk mengetahui perbedaan pencapaian kemampuan pemecahan masalah matematis antara siswa yang mendapatkan model pembelajaran Learning Cycle $7 E$ dan Problem Based Learning. Hasil dari penelitian menyimpulkan bahwa tidak terdapat perbedaan peningkatan kemampuan pemecahan masalah matematis antara siswa yang mendapatkan model pembelajaran Learning Cycle $7 E$ dan Problem Based Learning. Sementara itu, untuk kualitas peningkatan kemampuan pemecahan masalah matematis siswa yang mendapatkan model pembelajaran Learning Cycle $7 E$ dan Problem Based Learning masing-masing berinterpretasi sedang namun skor perolehan nya berbeda. Secara umum, sikap siswa terhadap pembelajaran matematika menggunakan model pembelajaran Learning Cycle $7 E$ dan Problem Based Learning masing-masing berinterpretasi baik. Kata Kunci: Pemecahan Masalah Matematis, Learning Cycle 7E, Problem Based Learning.
\end{abstract}

\begin{abstract}
Students' Problem Solving Ability through Learning Cycle 7E and Problem Based Learning)

Currently mathematical problem solving ability was a part of mathematics curriculum. In fact, the mathematical problem solving ability of students was not optimized, one of the reasons is there are still many students who have problems in terms of understanding the basic concepts. To optimizing the mathematical problem solving ability of students, it, can be reached by implementing student-centered learning. Learning Cycle $7 E$ and Problem Based Learning are two of a lot of student-centered learning models. The purpose of this study was to determine the difference of achievement mathematical problem solving ability between students who get Learning Cycle $7 E$ and Problem Based Learning models. The results of this study are there is not a difference enhancement of mathematical problem solving ability between students who get Learning Cycle $7 E$ and Problem Based Learning models. Meanwhile, the quality of enhancement mathematical problem solving ability students who get Learning Cycle 7E and Problem Based Learning models are in the middle interpretation. In general, students' attitudes toward learning mathematics using Learning Cycle $7 E$ and Problem Based Learning models each in good interpretation.

Keywords: Mathematical Problem Solving, Learning Cycle 7E, Problem Based Learning
\end{abstract}


http://journal.institutpendidikan.ac.id/index.php/mosharafa

I. Pendahuluan

Pemecahan masalah memiliki sejarah panjang dan sukses dalam pendidikan matematika dan dihargai oleh banyak guru sebagai cara untuk terlibat dan memfasilitasi pembelajaran dalam kelas mereka (Bella, Saijah \& Saragih, 2013). Sebagai salah satu dari kemampuan dasar yang diungkapkan oleh NCTM (2000), kemampuan pemecahan masalah memiliki peran penting dalam kurikulum saat ini. Hal ini termuat dalam Departemen Pendidikan Nasional (2006:34) bahwa pemecahan masalah hendaknya menjadi titik sentral dari kurikulum matematika dan menjadi bagian tidak terpisahkan dari pembelajaran matematika. Dengan pemecahan masalah (problem solving) dalam pembelajaran matematika diharapkan siswa akan mampu membangun pengetahuan baru tentang matematika, memecahkan masalah yang muncul dalam matematika ataupun dalam konteks kehidupan keseharian, mengaplikasikan dan mengadaptasi berbagai macam strategi yang cocok untuk memecahkan masalah, serta memonitor dan merefleksikan proses pemecahan masalah matematika. Kemampuan pemecahan masalah menuntut siswa untuk lebih aktif dalam mencari data, mengumpulkan data menjadi sebuah konsep, teori dan atau kesimpulan.

Beberapa peneliti telah banyak melakukan penelitian mengenai kemampuan pemecahan masalah siswa di Indonesia, diantaranya penelitian yang dilakukan oleh Putri (2014) yang mengungkapkan bahwa pada kemampuan pemecahan masalah matematis, siswa pada umumnya belum mampu memahami suatu konsep matematika sebelum diberikan arahan dari guru. Siswa senantiasa memerlukan penjelasan awal dari guru mengenai arah suatu konsep matematika yang akan dipelajari. Idealnya pembelajaran lebih menekankan peranan aktif siswa, dan guru lebih diharapkan untuk menjadi motivator dan fasilitator dalam proses pembelajaran. Oleh karena itu, dalam proses pembelajaran harus menggunakan model pembelajaran agar sarana interaksi antara guru dan siswa berlangsung dengan baik dan siswa yang lebih aktif dalam proses pembelajaran. Vernandez, Llinares \& Valls (2013) mengungkapkan bahwa rendahnya kemampuan pemecahan masalah matematis siswa, disebabkan karena guru kurang kreatif dalam mendesain tugas matematika yang melibatkan kegiatan pemecahan masalah.

Salah satu solusi dalam mendesain kegiatan pembelajaran yang menarik adalah penggunaan model pembelajaran yang berorientasi pada siswa. Model pembelajaran Learning Cycle $7 E$ adalah suatu model pembelajaran yang berpusat pada siswa. Fajaroh (dalam Suardi, 2013) mengemukakan bahwa Learning cycle adalah suatu model pembelajaran yang berpusat pada siswa (student centered) yang merupakan rangkaian tahap-tahap kegiatan yang diorganisasi sedemikian rupa sehingga siswa dapat menguasai kompetensi yang harus dicapai dalam pembelajaran dengan berperan aktif. Pengetahuan dikonstruksi dari pengalaman siswa. Hal ini sesuai dengan pendapat Shoimin (2014: 59) bahwa ciri khas model pembelajaran cycle learning adalah setiap siswa secara individu belajar materi pembelajaran yang sudah dipersiapkan guru. Kemudian, hasil belajar individual dibawa ke kelompok- 
kelompok untuk didiskusikan oleh anggota kelompok dan semua anggota kelompok bertanggung jawab secara bersama-sama atas keseluruhan jawaban. Shoimin (2014:61) juga menyebutkan bahwa implementasi Cycle Learning dalam orientasi pembelajaran adalah investigasi dan penemuan yang merupakan pemecahan masalah. Menurut Eisenkraft (dalam Suardi, 2013) tahapan-tahapan model pembelajaran Learning Cycle 7E meliputi Elicit (memunculkan pemahaman awal siswa), Engagment (melibatkan), Exploration (menyelidiki), Explaination (menjelaskan), Elaboration (menguraikan), Evaluation (menilai), Extend (memperluas).

Selain Learning Cycle 7E, model pembelajaran lain yang juga berorientasi pada siswa adalah Problem Based Learning dan disingkat PBL. PBL yaitu model pembelajaran yang mempunyai ciri adanya permasalahan nyata sebagai konteks untuk siswa belajar berpikir kritis dan keterampilan memecahkan masalah. Shoimin (2014) mengemukakan bahwa pembelajaran berbasis masalah lebih cocok untuk pembelajaran yang menuntut kemampuan tertentu yang kaitannya dengan pemecahan masalah.

Pemecahan masalah merupakan kemampuan yang mampu membangun pengetahuan dalam matematika atau dalam konteks kehidupan keseharian (nyata). Kemampuan tersebut dapat didukung dengan model pembelajaran Learning Cycle TE dan Problem Based Learning dimana kedua model tersebut merupakan model pembelajaran yang menghubungkan materi pembelajaran dengan kehidupan sehari-hari, mengedepankan sebuah masalah yang harus di pecahkan oleh siswa dengan pengetahuan yang dimilikinya. Menurut Rusmono (2012:81) untuk melaksanakan pembelajaran dengan strategi pembelajaran Problem Based Learning, ada lima tahap pembelajaran sebagai berikut:

1. Mengorganisasikan siswa kepada masalah

2. Mengorganisasikan siswa untuk belajar

3. Membantu penyelidikan mandiri dan kelompok

4. Mengembangkan dan mempresentasikan hasil karya serta pameran

5. Menganalisis dan mengevaluasi proses pemecahan masalah

Penelitian yang dilakukan oleh Sinaga (2017), Darojat dan Kartono (2016), Sari dkk (2015), dan Susanti dkk (2016), mengemukakan bahwa model pembelajaran Learning Cycle $7 E$ terbukti dapat memberikan pengaruh dan meningkatkan kemampuan matematis siswa. Penelitian lainnya yang dilakukan oleh Fauziah (2017), Mudzakin (2016), Laelasari (2016), Nadhifah (2016), dan Audria (2016), mengemukakan bahwa pencapaian kemampuan matematis siswa yang menggunakan model Problem Based Learning (PBL) adalah lebih baik dan PBL memberikan pengaruh dalam peningkatan kemampuan matematis siswa.

Berdasarkan pemaparan di atas, tujuan utama dari penelitian ini adalah menelaah perbedaan peningkatan kemampuan pemecahan masalah matematis antara siswa yang mendapatkan model pembelajaran Learning Cycle $7 E$ dan model pembelajaran Problem Based Learning. Selain itu, dalam penelitian juga melihat kualitas peningkatan kemampuan pemecahan masalah matematis siswa dan respon siswa terhadap kedua model pembelajaran. 
http://journal.institutpendidikan.ac.id/index.php/mosharafa

Dari tabel 1, terlihat bahwa skor pretest

\section{Metode}

Penelitian ini merupakan penelitian kuantitatif dengan menggunakan desain kelompok Kontrol Non-Ekuivalen (the nonequivalent control group design) yang melibatkan dua kelompok, ada pretest, posttest. Populasi dalam penelitian ini adalah seluruh siswa SMP Negeri 3 Garut kelas VIII dan dari populasi tersebut diambil dua kelas sebagai sampel secara purposive sampling yaitu kelas VIII-E sebagai eksperimen I dan kelas VIII-C sebagai eksperimen II.

\section{HASIL dAN PEMBahasan}

\section{A. HASIL PENELITIAN}

Tes kemampuan pemecahan masalah matematis dilakukan sebanyak dua kali yaitu tes awal (pretest) dan tes akhir (posttest) dengan soal yang sama. Hasil dari kedua tes tersebut kemudian dianalisis untuk menjawab rumusan masalah penelitian. Adapun hasil dari test awal (Pretest) dan tes akhir (Posttest) dari kedua kelas diperoleh sebagai berikut:

Tabel 1

Statistik Deskriptif Kemampuan Pemecahan Masalah Matematis

\begin{tabular}{l}
\hline \multicolumn{4}{c}{ Kelas } \\
\hline
\end{tabular}

maupun posttest kelas LC 7E (Learning Cycle 7E) lebih besar dibandingkan dengan kelas PBL (Problem Based Learning), sedangkan jika dilihat dari hasil simpangan baku, kelas PBL lebih rendah dari kelas LC 7E, hal tersebut menunjukkan bahwa kemampuan pemecahan masalah matematis kelas PBL lebih menyebar atau data yang semakin terpusat. Hasil analisis terhadap data pretest dari kelas LC 7E dan PBL menyimpulkan bahwa tidak terdapat perbedaan kemampuan awal antara siswa kelas Learning Cycle $7 E$ dan siswa kelas Problem Based Learning.

Selanjutnya perhitungan dilanjutkan terhadap peningkatan kemampuan pemecahan masalah matematis siswa. Hasil analisis secara statistik menyimpulkan bahwa tidak terdapat perbedaan peningkatan kemampuan pemecahan masalah matematis antara siswa yang mendapatkan model pembelajaran LC 7E dan PBL.

Hasil analisis terhadap data posttest dari kelas LC 7E dan PBL menyimpulkan bahwa hasil uji normalitas data kedua kelas tersebut berdistribusi normal, maka untuk pengujian selanjutnya dilakukan uji homogenitas dua varians, diperoleh kedua varians homogen. Selanjutnya untuk menguji kesamaan dua ratarata kemampuan akhir siswa setelah diberikan perlakuan adalah dengan uji-t.

Sebelum melakukan perhitungan, peneliti membuat rumusan hipotesis nol dan hipotesis alternatif nya terlebih dahulu, yaitu:

Ho: Tidak terdapat perbedaan kemampuan pemecahan masalah matematis antara siswa yang mendapatkan model 
pembelajaran Learning Cycle 7E dan

Problem Based Learning

Ha: Terdapat perbedaan kemampuan pemecahan masalah matematis antara siswa yang mendapatkan model pembelajaran Learning Cycle $7 E$ dan Problem Based Learning

Setelah melakukan perhitungan diperoleh kesimpulan bahwa terdapat perbedaan pencapaian kemampuan pemecahan masalah matematis antara siswa yang mendapatkan model pembelajaran Learning Cycle $7 E$ dan Problem Based Learning.

Tabel 2

Deskriptif Data Gain Ternormalisasi

\begin{tabular}{cccc|}
\hline Kelas & $\mathbf{N}$ & $\overline{\boldsymbol{x}}$ & Interpretasi \\
\hline$L C 7 E$ & 38 & 0,48 & Sedang \\
\hline$P B L$ & 38 & 0,36 & Sedang \\
\hline
\end{tabular}

Dari tabel 2, kualitas peningkatan kemampuan pemecahan masalah matematis siswa kelas LC 7E ataupun kelas PBL keduanya berinterpretasi sedang, namun memiliki perbedaan perolehan skor.

Tabel 3

Rekapitulasi Interpretasi Sikap Siswa Secara Umum

\begin{tabular}{ccc|}
\hline Kelas & Skor Total & Interpretasi \\
\hline$L C 7 E$ & 2766 & Baik \\
\hline$P B L$ & 2946 & Baik \\
\hline
\end{tabular}

Dari tabel 3, berdasarkan hasil penyebaran angket dengan menggunakan Skala Likert, secara umum kelas LC 7E dan kelas PBL ada dalam interpretasi sedang.

\section{B. PEMBAHASAN}

Berdasarkan hasil uji statistik di dapat kesimpulan bahwa tidak terdapat perbedaan peningkatan kemampuan pemecahan masalah matematis antara siswa yang mendapatkan model pembelajaran Learning Cycle $7 E$ dan siswa yang mendapatkan model pembelajaran
Problem Based Learning. Kesimpulan ini bukan berarti bahwa tidak ada perubahan kemampuan pemecahan masalah matematis siswa setelah diberi perlakuan, melainkan peningkatan antara siswa yang mendapatkan model pembelajaran Learning Cycle $7 E$ dan siswa yang mendapatkan model pembelajaran Problem Based Learning tidak berbeda secara signifikan.

Menelaah hasil uji posttest yaitu pencapaian kemampuan pemahaman matematis, siswa pada kelas Learning Cycle $7 E$ memperoleh rata-rata posttest sebesar $54,35 \%$ dan kelas Problem Based Learning memperoleh rata-rata posttest sebesar 42,25\%. Perbedaan perolehan kedua nilai tersebut bukan berarti siswa pada mendapatkan model pembelajaran Learning Cycle $7 E$ lebih unggul dari pada siswa yang mendapatkan model pembelajaran Problem Based Learning, karena hasil uji pretest terhadap kedua kelas secara deskripsi, rata-rata siswa pada kelas Learning Cycle 7E memang lebih besar.

Kualitas peningkatan kemampuan pemecahan masalah matematis antara siswa yang mendapatkan pembelajaran Learning Cycle $7 E$ dan Problem Based Learning keduanya berinterpretasi sedang. Perolehan skor siswa di kelas Learning Cycle $7 E$ sebesar 52,63\%, sedangkan skor siswa di kelas Problem Based Learning sebesar $47,37 \%$.

Untuk sikap siswa terhadap model pembelajaran Learning Cycle $7 E$, diperoleh skor sebesar 2766 dengan interpretasi baik. Hal ini berarti sikap siswa terhadap model pembelajaran Learning Cycle $7 E$ menunjukkan sikap yang baik dan dapat diterima oleh siswa. Sementara itu, sikap siswa yang mendapatkan model pembelajaran Problem Based Learning 
http://journal.institutpendidikan.ac.id/index.php/mosharafa

memperoleh skor sebesar 2946 dengan guru. Siswa senantiasa memerlukan interpretasi baik, ini juga berarti model pembelajaran Problem Based Learning dapat diterima oleh siswa.

Berdasarkan pemaparan hasil uji statistik, ada beberapa faktor yang turut mempengaruhi tidak adanya perbedaan peningkatan kemampuan pemecahan masalah di antara kedua kelas, diantaranya:

a. Pada kelas Learning Cycle $7 E$, siswa berpikir secara lebih mandiri bagaimana langkah atau strategi menyelesaikan soal-soal yang ada pada tahap Elaboration dan Evaluation, begitu pula pada kelas Problem Based Learning pemberian masalah di awal pembelajaran tanpa adanya penjelasan terlebih dahulu dari guru, menuntut siswa untuk berfikir secara mandiri.

b. Ketika proses pembelajaran, pada kelas Learning Cycle 7E, ada beberapa siswa yang bertanya kepada guru ketika diberikan lembar kerja, dan selanjutnya siswa mengerjakan secara mandiri soal-soal pada Lembar Kerja. Begitu pula pada kelas Problem Based Learning, di awal pemberian lembar kerja, beberapa perwakilan dari kelompok meminta guru menjelaskan bagian yang belum dipahami. Peran serta guru dalam kedua model ini hanya sebagai fasilitator. Kedua model ini memfasilitasi siswa untuk belajar secara aktif dalam mencari solusi permasalahan yang diberikan. Sejalan dengan hasil penelitian Putri (2014) mengemukakan bahwa berdasarkan hasil penelitian pada kemampuan pemecahan masalah matematis, siswa pada umumnya belum mampu memahami suatu konsep matematika sebelum diberikan arahan dari

penjelasan awal dari guru mengenai arah suatu konsep matematika yang akan mereka pelajari.

c. Siswa pada kelas Learning Cycle 7E maupun siswa pada kelas Problem Based Learning, mampu menunjukkan peningkatan kemampuan pemecahan masalah dengan kualitas peningkatannya dalam kategori sedang. Hal ini sejalan dengan penelitian Darojat dan Kartono (2016), model pembelajaran Learning Cycle $7 E$ terbukti dapat meningkatkan pemecahan masalah matematis siswa. Begitu pula dengan pendapat Shoimin (2014) bahwa pembelajaran berbasis masalah lebih cocok untuk pembelajaran yang menuntut kemampuan tertentu yang kaitannya dengan pemecahan masalah. Penelitian ini juga mendukung penelitian sebelumnya yang menyimpulkan bahwa baik model pembelajaran Learning Cycle $7 E$ maupun model pembelajaran Problem Based Learning, keduanya mampu memberikan pengaruh terhadap kemampuan pemecahan masalah matematis.

\section{Penutup}

Berdasarkan hasil analisis dan pembahasan secara keseluruhan terhadap data penelitian mengenai perbedaan peningkatan kemampuan pemecahan masalah matematis siswa yang mendapatkan model pembelajaran Learning Cycle 7E dan Problem Based Learning, disimpulkan bahwa tidak terdapat perbedaan peningkatan kemampuan pemecahan masalah matematis antara siswa yang mendapatkan model pembelajaran Learning Cycle TE dan 
Lestari \& Rosdiana

Problem Based Learning, dengan kualitas peningkatan kemampuan pemecahan masalah matematis siswa yang mendapatkan model pembelajaran Learning Cycle 7E dan Problem Based Learning ada dalam interpretasi sedang, dan sikap siswa terhadap model pembelajaran Learning Cycle $7 E$ maupun model pembelajaran Problem Based Learning ada dalam interpretasi baik. Ini berarti, kedua model pembelajaran ini sudah mampu meningkatkan kemampuan pemecahan masalah matematis siswa, namun belum optimal karena pencapaian kemampuan pemecahan masalah matematis siswa masih dibawah 60\%.

\section{DAFTAR PUSTAKA}

Audria, V. (2017). Perbedaan Kemampuan Penalaran Deduktif Matematis Siswa antara yang Mendapatkan Model Pembelajaran Problem Based Learning dan Model Pembelajaran Information Processing. Skripsi pada jurusan Pendidikan Matematika STKIP-Garut. Tidak diterbitkan.

Darojat dan Kartono. (2016). Kemampuan Pemecahan Masalah Siswa dalam Menyelesaikan Soal Open Ended berdasarkan AQ dengan Learning Cycle 7E. [Online].

Tersedia:https://journal.unnes. ac.id/sju/index.php/ujmer/a rticle/download/12908/7044.

[14 maret 2018]

Departemen Pendidikan Nasional. (2006). Pedoman Penulisan Buku Pelajaran, Penjelasan Standar Mutu Buku Pelajaran Matematika. Jakarta: Pusat Perbukuan Depdiknas.
p-ISSN: $2086-4280$

e-ISSN: $2527-8827$

Fauziah, H. (2017). Perbandingan Kemampuan Komunikasi Matematis Siswa antara yang Mendapatkan Model Pembelajaran Problem Based Learning (PBL) dengan Model Pembelajaran Direct Instruction (DI). Skripsi pada jurusan Pendidikan Matematika STKIP-Garut. Tidak diterbitkan.

Fernandez, F., Llinares, S., \& Valls, J., (2013). Primary school teacher's noticingof students' mathematical thinking in problem solving. Journal of The Mathematics Enthusiast, ISSN 15513440, Vol. 10, nos.1\&2, pp.441-468 2013.

Laelasari. (2016). Perbandingan Peningkatan Kemampuan Komunikasi Matematis Antara Siswa Yang Pembelajarannya Dengan Problem Based Learning (PBL) Dan Siswa Yang Pembelajarannya Dengan Model Make A Match. Skripsi pada prodi Pendidikan Matematika STKIP - Garut: Tidak diterbitkan

Mudzakin, F. (2016). Perbedaan peningkatan kemampuan pemecahan masalah matematis antara siswa yang mendapatkan metode problem based learning dengan metode discovery learning. Skripsi pada jurusan Pendidikan Matematika STKIP-Garut: Tidak Diterbitkan.

Nadhifah, G. (2015). Perbedaan Kemampuan Pemecahan Masalah Matematika antara siswa yang mendapatkan pembelajaran Problem Based Learning (PBL) dengan pembelajaran inquiry. Skripsi pada jurusan Pendidikan Matematika STKIPGarut: Tidak diterbitkan. 
http://journal.institutpendidikan.ac.id/index.php/mosharafa

NCTM. (2000). Principles and Standard for School Mathematics. Reston: NCTM.

Putri, A. (2014). Perbedaan Kemampuan Pemecahan Masalah Matematis siswa antara yang mendapatkan Model Pembelajaran Probing Prompting dengan Model Pembelajaran Open Ended. Skripsi pada jurusan Pendidikan Matematika STKIP-Garut: Tidak diterbitkan.

Rusmono. (2014). Strategi Pembelajaran dengan Problem Based Learning itu perlu. Bogor:Ghalia Indonesia.

Sari, dkk. (2015). Pengaruh Model Learning Cycle 7E terhadap Kemampuan Pemecahan Masalah Matematis Siswa Sekolah Dasar. [Online].Tersedia:

https://scholar.google.co.id/scholar?hl= en\&as_sdt=0,5\&cluster $=181518507740$ 17171931

Shoimin, A. (2014). 68 Model Pembelajaran Inovatif dalam Kurikulum 2013. Yogyakarta: Ar-Ruzz Media.

Sinaga, C. (2017). "Peningkatan Kemampuan Pemecahan Masalah Matematis dan Productive Disposition Siswa SMP melalui Model Pembelajaran Learning cycle 7E". FKIP UNPAS. [online]. Tersedia: http://jurnalnasional.ump.ac.id/index.ph p/alphamath/article/view/210/206

Suardi, M. (2013). Model pembelajaran learning cycle. [online]. Tersedia: http://suardimaswatu.blogspot.co.id/20 13/03/skripsi-model-pembelajaran learning.html. [29 Mei 2017]

Sumarmo, U. (2013). Berpikir dan Disposisi Matematik serta Pembelajarannya.
Kumpulan Makalah. Jurdikmat FMIPA UPI.

Susanti dkk. (2016). Pengaruh Model Pembelajaran Learning Cycle $7 E$ terhadap Kemampuan Pemecahan Masalah Matematika Bagi Siswa Kelas X MIA SMA Kristen Satya Wacana Salatiga. [Online]. Tersedia:

http://repository.uksw.edu/bitstream/1 23456789/9826/2/T1_202012035_Full\% 20text.pdf 